\title{
Submental Artery Island Flap in Oral Cavity Reconstruction. An Observational, Retrospective Two-centre Study
}

\author{
Adonis Tupac Ramirez ${ }^{1}$ Carlos Miguel Chiesa-Estomba ${ }^{2}$ José Ángel González-García² \\ ${ }^{1}$ Department of Head and Neck Surgery, Clínica Medilaser, Neiva, \\ Address for correspondence Carlos Miguel Chiesa-Estomba, MD, \\ Huila, Colombia \\ 2 Department of Otorhinolaryngology - Head and Neck surgery, \\ Hospital Universitario Donostia, San Sebastian - Donosti, \\ Guipuzkoa - Basque, Spain \\ MSc, Department of Otorhinolaryngology - Head and Neck Surgery, \\ Hospital Universitario Donostia, Calle Dr. Begiristain \#1 CP: 20007, \\ San Sebastian - Donosti, Guipuzkoa - Basque, España \\ (e-mail: chiesaestomba86@gmail.com).
}

Int Arch Otorhinolaryngol 2021;25(1):e71-e76.

\begin{abstract}
Introduction The submental flap provides an alternative technique in orofacial reconstruction, especially in situations in which free flaps are not available, or the patients are unfit.

Objective To demonstrate the oncological safety and benefits of this flap in oral cavity reconstruction.

Methods A total of 14 patients with oral cavity cancers, who underwent submental flap reconstruction from January 2016 to January 2018, were included in the study.

Results There were 11 male and 3 female patients with a mean age of $66.7 \pm 14$ (Min: 52/Max: 91) years old. The most common primary tumor site was the mobile tongue in $12(85.7 \%)$ patients. All of the patients underwent ipsilateral selective neck dissection after the flap was harvested. Flap partial necrosis was observed in one patient, and total necrosis in another one. The mean follow-up was of one year. Nonlocal or regional

Keywords

- head

- neck

- oral cavity

- reconstruction recurrences were observed.

Conclusion Submental island flap represents a good option in oral cavity reconstruction in a restricted setting or in patients considered not fit for free flap reconstruction. Preoperative selection of clinically neck node-negative patients is essential due to the potential risk of occult metastasis.
\end{abstract}

\section{Introduction}

Oral squamous cell carcinoma (OSCC) represents the sixth most common cancer worldwide and usually affects middleaged and elderly individuals. ${ }^{1-3}$ This kind of tumors may compromise the mucosa of the floor of the mouth, the cheek, the tongue and the inner lip surface, being the oral tongue the most common oral subsite affected. ${ }^{4}$

received

October 8, 2019

accepted

January 30, 2020

published online

April 24, 2020
DOI https://doi.org/ 10.1055/s-0040-1709115. ISSN 1809-9777.
Reconstruction of soft tissue defects of the oral cavity represents a complex surgical situation. Nowadays, the use of microvascular free flaps is considered the gold standard. However, its use elevates costs for healthcare providers, requires surgical team expertise, prolonged surgical time and prolonged hospital stay. Therefore, a free flap is not always the ideal option or can be contraindicated. In these cases, locoregional flaps represent a valid alternative. Also, locoregional
๑ 2020. Fundação Otorrinolaringologia. All rights reserved.

This is an open access article published by Thieme under the terms of the Creative Commons Attribution-NonDerivative-NonCommercial-License, permitting copying and reproduction so long as the original work is given appropriate credit. Contents may not be used for commercial purposes, or adapted, remixed, transformed or built upon. (https://creativecommons.org/ licenses/by-nc-nd/4.0/)

Thieme Revinter Publicações Ltda., Rua do Matoso 170, Rio de Janeiro, RJ, CEP 20270-135, Brazil 
flaps can work as a backup preautonomized flap when partial or total necrosis develops in previously placed locoregional or free flaps, which requires a salvage procedure. ${ }^{5}$ This explains the resurrection of several local and regional flaps in recent years, ${ }^{6}$ and why nowadays pedicled and free flaps have concurred for the same indications in many cases. ${ }^{6}$

In centers without experience or access to microsurgical reconstruction, pedicled flaps play a fundamental role in head and neck reconstruction. However, they do have limitations, including unpredictable viability and limited mobility.

The submental artery island flap (SAIF) was initially described by Martin et al in 1993 for facial defect reconstruction as an alternative to free flaps due to its color, shape and texture. ${ }^{7}$ Three years later, Sterne et $\mathrm{al}^{8}$ described the use of the SAIF in oncological oral cavity reconstruction after ablative surgery, and over the last few years the SAIF has proven to be a reliable reconstructive option in head and neck surgery. ${ }^{9}$ However, in the literature, some reports highlight the risk of reconstructing the oral cavity using the SAIF, due to the potential compromise of the neck nodal clearance. ${ }^{10}$

The submental artery has a constant vascular branch that arises from the facial artery. It courses forward and medially between the submandibular gland and the mylohyoid muscle. The artery usually travels either deep (70\%) or superficial (30\%) to the anterior belly of the digastric muscle, and finishes behind the mandibular symphysis. ${ }^{11}$ Along its course, cutaneous perforators pierce the platysma and anterior belly of the digastric muscles to constitute the subdermal plexus forming extensive anastomoses with the contralateral artery. The submental vein drains into the facial vein, communicating with both the internal and external jugular veins. ${ }^{12,13}$ The SAIF has a long $(8 \mathrm{~cm})$ consistent and reliable pedicle, and cutaneous dimensions can reach up to $6 \mathrm{~cm} \times 12 \mathrm{~cm}$. Moreover, the SAIF can be used as a cutaneous, musculofascial (cervicofacial and platysma), or osteocutaneous flap, and the donor site defect can be primarily closed without functional or cosmetic deficit. ${ }^{14}$

The present study aims to share a two-center experience using the SAIF, and to describe the complications related to the use of the flap and also short-term oncological outcomes and recurrence rates during the follow-up of the included patients.

\section{Method}

This was a retrospective study performed in two centers with the same surgical and reconstructive philosophy (Clínica Medilaser [CMN] and the Hospital Universitário Donostia [HUD]). Approval by the ethics committees of both hospitals was obtained. Patients diagnosed with stages I and II OSCC according to the criteria of the Union Internationale Contre le Cancer (UICC) and the American Joint Committee on Cancer (AJCC-7th edition), previously untreated, with clinical and radiologic N0 neck who were considered candidates for this kind of reconstructive surgery were included. The reason why the SAIF flap was chosen as an option to reconstruct the oral cavity after ablative surgery according to each center experience was highly selected availability for microsurgical free flap reconstruction (CMN) or due to the patient's comorbidities (CMN and HUD).

The surgical technique used was a standard SAIF previously described by other authors ${ }^{15}$ ( - Fig. 1). Statistical analysis was conducted with SPSS for Macintosh Version 21.0 (IBM Corp., Armonk, NY, USA). Categorical data are presented as frequencies and percentages. Continuous data are presented as means and standard deviations [SD].

\section{Results}

A total of 14 patients requiring an OSCC ablative surgery, reconstructed with a SAIF between January 2016 and January 2018 were included. There were 11 (78.6\%) male and 3 (21.4\%) female patients with amean age of 66.714 (Min: 52/ Max: 91 ) years old. Tumor sites involved were the tongue in $12(85.7 \%)$ patients, the inferior lip in $1(7.15 \%)$ patient, and the soft palate in 1 (7.15\%) patient ( - Fig. 2 and $\mathbf{3}$ ). All of the patients underwent ipsilateral or bilateral selective neck dissection after flap harvest. A total of 2 (14.3\%) patients had a postoperative flap complication, one of them suffered partial necrosis of the flap and another patient suffered total necrosis of the flap. The mean hospital stay was 8-11 days (Min: 6/Max: 23 days), and the mean follow-up was of 12 months. None of them developed a local or regional recurrence during the follow-up. A total of 12 patients were alive
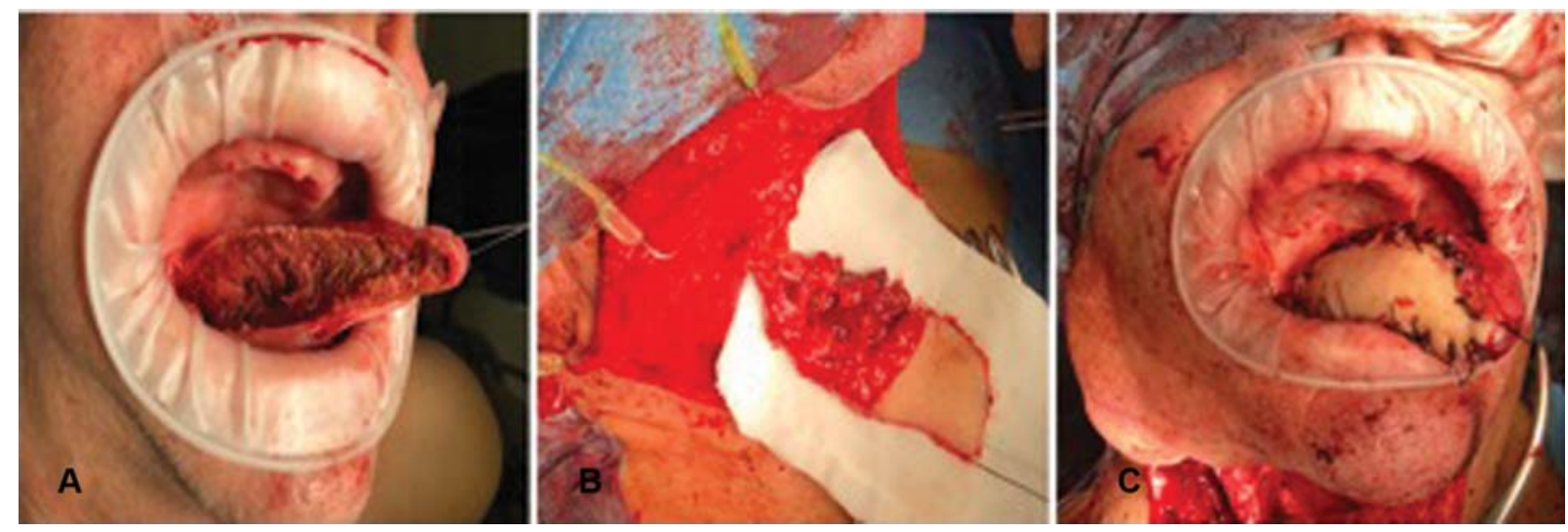

Fig. 1 Oral tongue reconstruction after ablative surgery. (A) Oral Tongue after resection. (B) Submental Flap. (C) Submental flap in the recipient site. 

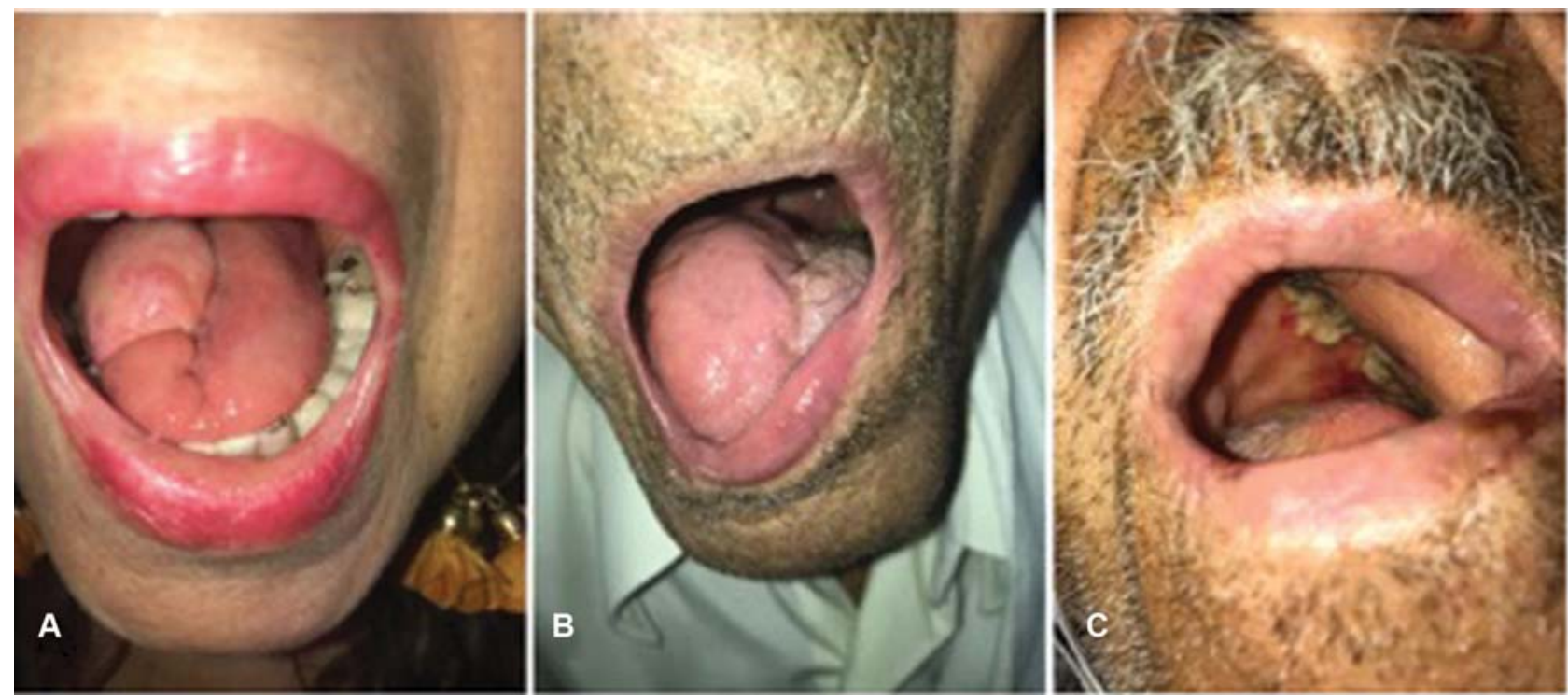

Fig. 2 Post-operative results after submental artery island flap reconstruction of the oral tongue. (A) right hemiglossectomy. (B) left partial glossectomy. (C) soft palate.
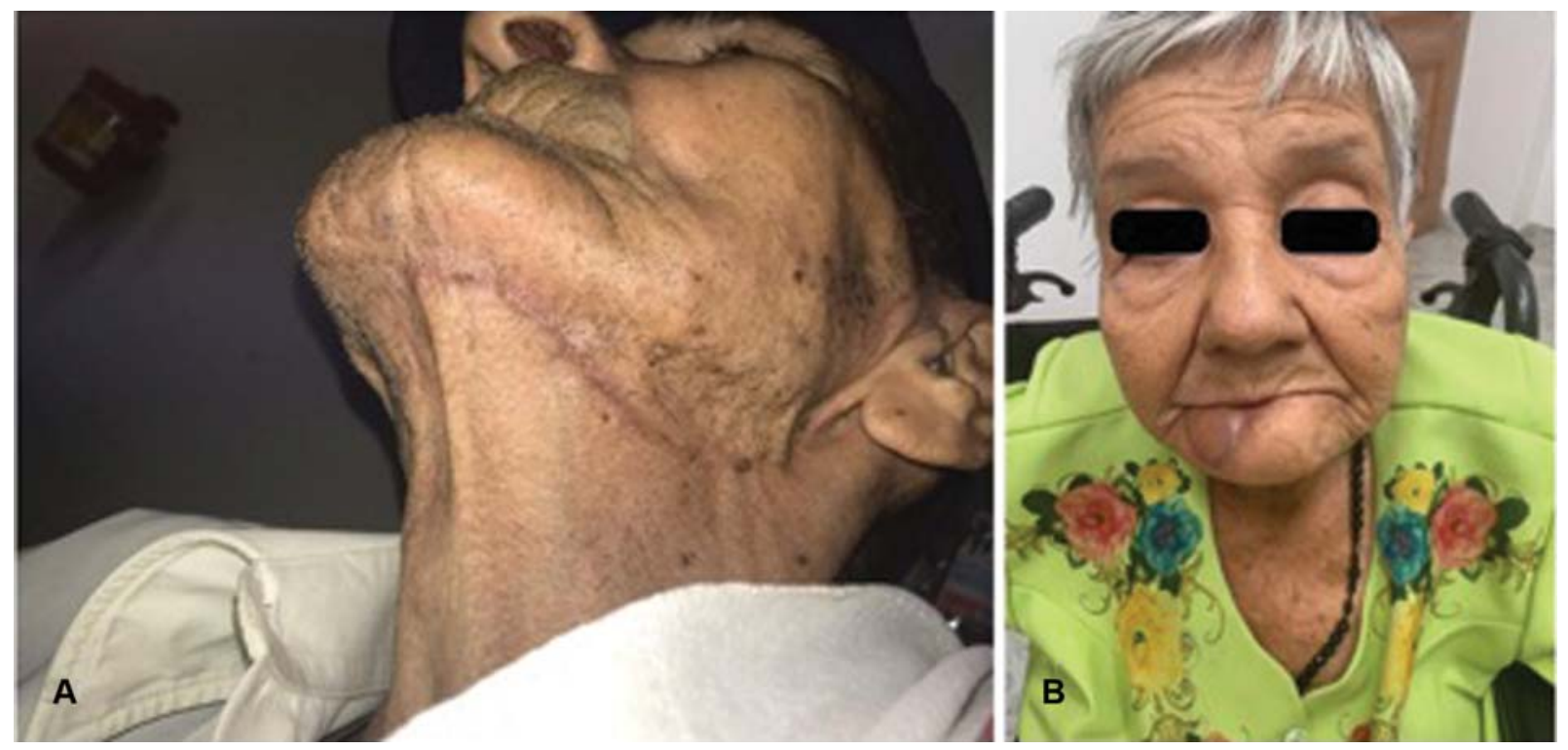

Fig. 3 (A) Donor site (B) Lip Reconstruction.

and 2 died during this period, one of them due to a heart attack and another due to an iliofemoral bypass rupture. In all cases, the marginal mandibular nerve was preserved. (-Table 1).

\section{Discussion}

The use of free flaps has been accepted as the primary option for reconstruction of soft or hard tissue defects in OSCC patients after ablative oncological surgery. ${ }^{16,17}$ However, a free flap is not recommended in patients with vessel-depleted operated or irradiated necks or patients with a high American Society of Anesthesiologists (ASA) risk score. Moreover, operative surgical time is longer compared with the submental flap, and consequently, hospital stay, costs and postoperative medical complications are usually higher. ${ }^{11,18,19}$
The use of pedicled myocutaneous flaps is another excellent surgical option, characterized by technical simplicity and good blood supply..$^{20,21}$ However, the disadvantages of these flaps are the bulky volume, the requirement of secondary revisional surgeries and a higher rate of complications, especially in female patients. ${ }^{22,23}$

The SAIF is based on the submental artery, a constant branch of the facial artery, which originates in the facial artery from the external carotid artery. This artery has 5 main branches along its course toward the midline and anastomoses in $92 \%$ of the cases with the contralateral artery. ${ }^{24}$ It is located medially to the mandibular inferior border ${ }^{25}$ and represents the main blood supply of the floor of the mouth in $60 \%$ of the cases. ${ }^{26}$

In our experience, the flap has a long pedicle, a wide arc of rotation, and it can cover a large surface area. Techniques to 
74 Submental Artery Island Flap in Oral Cavity Reconstruction Ramirez et al.

Table 1 Demographic and clinical data

\begin{tabular}{|l|l|l|l|l|l|l|l|l|}
\hline & Age & Sex & Site & Stage & Complication & RT & Recurrence & Status \\
\hline Case 1 & 80 & female & Lip & pT2pN1M0 & Partial Necrosis & Yes & No & Alive \\
\hline Case 2 & 55 & Male & Soft Palate & pT2pN0M0 & None & No & No & Alive \\
\hline Case 3 & 62 & Male & Tongue & pT2pN1M0 & None & Yes & No & Alive \\
\hline Case 4 & 70 & Male & Tongue & pT2pN0M0 & None & No & No & Alive \\
\hline Case 5 & 65 & Male & Tongue & pT2pN0M0 & None & No & No & Alive \\
\hline Case 6 & 71 & Male & Tongue & pT2pN1M0 & None & Yes & No & Alive \\
\hline Case 7 & 58 & Male & Tongue & pT2pN1M0 & None & Yes & No & Alive \\
\hline Case 8 & 64 & Male & Tongue & pT2pN0M0 & None & No & No & Alive \\
\hline Case 9 & 62 & Female & Tongue & pT2pN0M0 & None & No & No & Alive \\
\hline Case 10 & 56 & Female & Tongue & pT2pN1M0 & None & No & No & Alive \\
\hline Case 11 & 61 & Male & Tongue & pT2pN1M0 & None & Yes & No & Alive \\
\hline Case 12 & 52 & Male & Tongue & pT2pN1M0 & None & Yes & No & Alive \\
\hline Case 13 & 88 & Male & Tongue & pT2pN0M0 & None & No & No & Dead \\
\hline Case 14 & 91 & Male & Tongue & pT2pN0M0 & Necrosis & No & No & Dead \\
\hline
\end{tabular}

Abbreviation: RT, radiation therapy.

elongate the pedicle used and described are the additional dissection of the pedicle, $\mathrm{Y}-\mathrm{V}$ procedure, the reverse flow flap, section of the facial vein and microvascular anastomosis. And their choice wants to be mainly conditioned by the site of the defect. ${ }^{27}$ Qualitatively, this flap is an ideal substitute for oral cavity or facial region defects, given the similarity of texture and also the possibility of primary closure with minimal aesthetic morbidity. ${ }^{28}$ The SAIF is a reliable alternative to microvascular free flaps, especially in older patients, or in those with severe comorbidities such as poor nutrition, aggressive medical conditions or other incurable diseases. These patients are not optimal candidates for a prolonged microvascular operation, and they require a nonaggressive treatment strategy with reduced surgical times, mainly when the reconstruction is limited to small or mediumsize defects. ${ }^{9,29,30}$

The SAIF may be employed for several purposes, mainly as myocutaneous, but also as fasciocutaneous, osteocutaneous or cutaneous flap, ${ }^{31}$ and it has been described for reconstruction of head and neck soft tissue defects of the lower, mid and upper region of the face (which may require division of the facial artery and vein). It has also been used for malar augmentation with fascia flap only, ${ }^{29,32}$ reconstruction of defects with hair-bearing skin, ${ }^{33}$ tongue and/or floor of mouth defects, buccal mucosa defects, palatal defects, ${ }^{34}$ nasal reconstruction, ${ }^{35}$ lip reconstruction, ${ }^{36-38}$ cervical esophagus repair or reconstruction, ${ }^{39-41}$ hemilaryngectomy defects repair, ${ }^{31}$ reconstruction of the neopharynx after total laryngectomy, repair of pharyngocutaneous fistulas ${ }^{42}$ and coverage of hardware used in spine surgery. ${ }^{43}$

There is controversy in the literature about the oncological safety of the SAIF due to the relationship between the flap and lymph nodes of the Ib region, because these nodal levels might be involved even at an early stage of OSCC, ${ }^{44,45}$ and this can increase the risk of recur- rence, ${ }^{44,46,47}$ as well as hindering a rigorous cervical level I neck dissection.

Nevertheless, the literature is contradictory concerning this. Sebastian et al claim that the submental flap should be avoided if there is any suspicion of level I involvement. ${ }^{9}$ Similarly, Vural et al have warned of the potential risk of this flap in patients with clinical or radiological evidence of level I cervical metastases. ${ }^{31}$ However, Sittitrai et al suggested that the submental flap could be used safely in a patient with level I metastatic involvement if the patients are adequately selected. ${ }^{14}$ Chow et al recommended that dissection in the subplatysmal plane would minimize the chances of tumor spread and inadequate clearance, ${ }^{48}$ and Amin et al prescribed the complete lymph node dissection before flap harvesting and recommend that this flap should be avoided in those patients with clinically advanced nodal disease in the neck (> N0). ${ }^{46}$ Taking into account the available evidence and given the different flaps available for oral reconstruction, the SAIF should be carefully indicated in patients with suspicion of level I involvement. However, it might constitute a useful weapon in the reconstruction of defects of traumatic origin.

The flap harvesting technique has been variable in the indexed literature. The inclusion of the anterior belly of the digastric muscle in the flap has been controversial. In our series, we have included the anterior belly of the digastric muscle to improve the blood supply. However, we must emphasize that the use of this flap is contraindicated in patients with a history of neck dissection because the integrity of the facial artery/vein is necessary. ${ }^{49}$ Also, ultrasound color Doppler with facial artery/vein and skin perforators localization can reduce the failure rate of the flap. ${ }^{50}$

Regarding complications, one patient suffered partial necrosis, and another suffered total necrosis of the flap. No other complications, such as bleeding or systemic infection, were observed during the postoperative period. 
The potential risk of injury to the marginal mandibular nerve during SAIF harvesting ranges from $0 \%$ to $17 \%{ }^{24,51}$ To reduce the risk of injury, Sterne et al recommend the identification of the nerve before raising the flap to avoid the damage. ${ }^{8}$ In our series, no patient developed a temporary marginal mandibular nerve palsy. Finally, we should highlight the retrospective nature of the study, the short followup period and the reduced number of cases included as limitations of the present study, which might limit the validity of its results.

\section{Conclusion}

The SAIF has shown promising results due to its versatility, wide arc of rotation, color match, and low donor site morbidity. Some controversies about the oncological safety of the procedure exist. However, it might constitute a useful weapon in head and neck reconstruction in well-selected patients.

\section{Conflict of Interests}

The authors have no conflict of interests to declare.

\section{References}

1 Jemal A, Siegel R, Ward E, Murray T, Xu J, Smigal C, Thun MJ. Cancer statistics, 2006. CA Cancer J Clin 2006;56(02):106-130

2 Kerawala C, Roques T, Jeannon JP, Bisase B. Oral cavity and lip cancer: United Kingdom National Multidisciplinary Guidelines. J Laryngol Otol 2016;130(Suppl 2):S83-S89

3 de Vicente JC, de Villalaín L, Torre A, Peña I. Microvascular free tissue transfer for tongue reconstruction after hemiglossectomy: a functional assessment of radial forearm versus anterolateral thigh flap. J Oral Maxillofac Surg 2008;66(11):2270-2275

4 Veness MJ, Morgan GJ, Sathiyaseelan Y, Gebski V. Anterior tongue cancer and the incidence of cervical lymph node metastases with increasing tumour thickness: should elective treatment to the neck be standard practice in all patients? ANZ J Surg 2005;75(03):101-105

5 Colletti G, Autelitano L, Tewfik K, Rabbiosi D, Biglioli F. Autonomized flaps in secondary head and neck reconstructions. Acta Otorhinolaryngol Ital 2012;32(05):329-335

6 Colletti G, Tewfik K, Bardazzi A, Allevi F, Chiapasco M, Mandalà M, Rabbiosi D. Regional flaps in head and neck reconstruction: a reappraisal. J Oral Maxillofac Surg 2015;73(03):571.e1-571.e10

7 Martin D, Pascal JF, Baudet J, Mondie JM, Farhat JB, Athoum A, et al. The submental island flap: a new donor site. Anatomy and clinical applications as a free or pedicled flap. Plast Reconstr Surg 1993;92 (05):867-873

8 Sterne GD, Januszkiewicz JS, Hall PN, Bardsley AF. The submental island flap. Br J Plast Surg 1996;49(02):85-89

9 Sebastian P, Thomas S, Varghese BT, Iype EM, Balagopal PG, Mathew PC. The submental island flap for reconstruction of intraoral defects in oral cancer patients. Oral Oncol 2008;44 (11):1014-1018

10 Cariati P, Cabello Serrano A, Marin Fernandez AB, Perez de Perceval Tara M, Juliá MA, Ildefonso Martinez Lara M. Is submental flap safe for the oncological reconstruction of the oral cavity? J Stomatol Oral Maxillofac Surg 2018;119(04):284-287

11 Patel UA, Bayles SW, Hayden RE. The submental flap: A modified technique for resident training. Laryngoscope 2007;117(01): 186-189

12 Potter S, De Blacam C, Kosutic D. True submental artery perforator flap for total soft-tissue chin reconstruction. Microsurgery 2012; 32(06):502-504
13 Matsui A, Lee BT, Winer JH, Laurence RG, Frangioni JV. Submental perforator flap design with a near-infrared fluorescence imaging system: the relationship among number of perforators, flap perfusion, and venous drainage. Plast Reconstr Surg 2009;124 (04):1098-1104

14 Sittitrai P, Srivanitchapoom C, Reunmakkaew D, Yata K. Submental island flap reconstruction in oral cavity cancer patients with level I lymph node metastasis. Br J Oral Maxillofac Surg 2017;55 (03):251-255

15 Schonauer F, Di Martino A, Nele G, Santoro M, Dell'Aversana Orabona G, Califano L. Submental flap as an alternative to microsurgical flap in intraoral post-oncological reconstruction in the elderly. Int J Surg 2016;33(Suppl 1):S51-S56

16 Cinar C, Ogur S, Arslan H, Kilic A. Adding versatility to the reconstruction of intraoral lining: opened pocket method. J Craniofac Surg 2007;18(01):198-202

17 Valentini V, Saltarel A, Cassoni A, Battisti A, Egidi S. One-stage reconstruction of a defect of the oral commissure and of the cheek with a radial forearm free flap. J Craniofac Surg 2008;19(06): 1508-1511

18 Kesting MR, Hölzle F, Wales C, Steinstraesser L, Wagenpfeil S, Mücke $\mathrm{T}$, et al. Microsurgical reconstruction of the oral cavity with free flaps from the anterolateral thigh and the radial forearm: a comparison of perioperative data from 161 cases. Ann Surg Oncol 2011;18(07):1988-1994

19 Paydarfar JA, Patel UA. Submental island pedicled flap vs radial forearm free flap for oral reconstruction: comparison of outcomes. Arch Otolaryngol Head Neck Surg 2011;137(01):82-87

20 Chavan KT, Reddy BP, Desai R, Manjunath S, Shubhalakshmi S, Umashankar KV. Versatility of pectoralis major myocutaneous flap. Int J Oral Maxillofac Surg 2007;36:1055

21 McLean JN, Carlson GW, Losken A. The pectoralis major myocutaneous flap revisited: a reliable technique for head and neck reconstruction. Ann Plast Surg 2010;64(05):570-573

22 Mehrhof AI Jr, Rosenstock A, Neifeld JP, Merritt WH, Theogaraj SD, Cohen IK. The pectoralis major myocutaneous flap in head and neck reconstruction. Analysis of complications. Am J Surg 1983; 146(04):478-482

23 El-Marakby HH. The reliability of pectoralis major myocutaneous flap in head and neck reconstruction. J Egypt Natl Canc Inst 2006; 18(01):41-50

24 Magden O, Edizer M, Tayfur V, Atabey A. Anatomic study of the vasculature of the submental artery flap. Plast Reconstr Surg 2004;114(07):1719-1723

25 Kim DH, Won SY, Choi DY, Kim HS, Jung UW, Kim HJ, Hu KS, et al. Topography of the submental artery that should be considered in bleeding during dentoalveolar surgery. J Craniofac Surg 2012;23 (05):1453-1456

26 Bavitz JB, Harn SD, Homze EJ. Arterial supply to the floor of the mouth and lingual gingiva. Oral Surg Oral Med Oral Pathol 1994; 77(03):232-235

27 Ferrari S, Copelli C, Bianchi B, Magri AS, Ferri A, Varazzani A, et al. The submental island flap: pedicle elongation and indications in head and neck reconstruction. J Craniomaxillofac Surg 2014;42 (06):1005-1009

28 Lee JC, Lai WS, Kao $\mathrm{CH}, \mathrm{Hsu} \mathrm{CH}$, Chu YH, Lin YS. Multipleparameter evaluation demonstrates low donor-site morbidity after submental flap harvesting. J Oral Maxillofac Surg 2013;71 (10):1800-1808

29 Chen WL, Li JS, Yang ZH, Huang ZQ, Wang JU, Zhang B. Two submental island flaps for reconstructing oral and maxillofacial defects following cancer ablation. J Oral Maxillofac Surg 2008;66 (06):1145-1156

30 Behan FC, Rozen WM, Wilson J, Kapila S, Sizeland A, Findlay MW. The cervico-submental keystone island flap for locoregional head and neck reconstruction. J Plast Reconstr Aesthet Surg 2013;66 (01):23-28 
31 Vural E, Suen JY. The submental island flap in head and neck reconstruction. Head Neck 2000;22(06):572-578

32 Tan O, Atik B, Parmaksizoglu D. Soft-tissue augmentation of the middle and lower face using the deepithelialized submental flap. Plast Reconstr Surg 2007;119(03):873-879

33 Demir Z, Kurtay A, Sahin U, Velidedeoğlu H, Celebioğlu S. Hairbearing submental artery island flap for reconstruction of mustache and beard. Plast Reconstr Surg 2003;112(02):423-429

34 Genden EM, Buchbinder D, Urken ML. The submental island flap for palatal reconstruction: a novel technique. J Oral Maxillofac Surg 2004;62(03):387-390

35 Tan O, Kiroglu AF, Atik B, Yuca K. Reconstruction of the columella using the prefabricated reverse flow submental flap: A case report. Head Neck 2006;28(07):653-657

36 Kitazawa T, Harashina T, Taira H, Takamatsu A. Bipedicled submental island flap for upper lip reconstruction. Ann Plast Surg 1999;42(01):83-86

37 Koshima I, Inagawa K, Urushibara K, Moriguchi T. Combined submental flap with toe web for reconstruction of the lip with oral commissure. Br J Plast Surg 2000;53(07):616-619

38 Yilmaz M, Menderes A, Barutçu A. Submental artery island flap for reconstruction of the lower and mid face. Ann Plast Surg 1997;39 (01):30-35

39 Janssen DA, Thimsen DA. The extended submental island lip flap: an alternative for esophageal repair. Plast Reconstr Surg 1998;102 (03):835-838

40 Zhang B, Wang JG, Chen WL, Yang ZH, Huang ZQ. Reverse facialsubmental artery island flap for reconstruction of oropharyngeal defects following middle and advanced-stage carcinoma ablation. Br J Oral Maxillofac Surg 2011;49(03):194-197

41 Wang WH, Hwang TZ, Chang CH, Lin YC. Reconstruction of pharyngeal defects with a submental island flap after hypopharyngeal carcinoma ablation. ORL J Otorhinolaryngol Relat Spec 2012;74(06):304-309
42 Demir Z, Velidedeoğlu H, Celebioğlu S. Repair of pharyngocutaneous fistulas with the submental artery island flap. Plast Reconstr Surg 2005;115(01):38-44

43 Abboud O, Shedid D, Ayad T. Reconstruction of the prevertebral space with a submental flap: a novel application. J Plast Reconstr Aesthet Surg 2013;66(12):1763-1765

44 Parmar PS, Goldstein DP. The submental island flap in head and neck reconstruction. Curr Opin Otolaryngol Head Neck Surg 2009;17(04):263-266

45 Elzahaby IA, Roshdy S, Shahatto F, Hussein O. The adequacy of lymph node harvest in concomitant neck block dissection and submental island flap reconstruction for oral squamous cell carcinoma; a case series from a single Egyptian institution. BMC Oral Health 2015;15:80

46 Amin AA, Sakkary MA, Khalil AA, Rifaat MA, Zayed SB. The submental flap for oral cavity reconstruction: extended indications and technical refinements. Head Neck Oncol 2011;3:51-57

47 Cheng MH, Lin CY, Patel KM. A prospective clinical assessment of anatomic variability of the submental vascularized lymph node flap. J Surg Oncol 2017;115(01):43-47

48 Chow TL, Chan TT, Chow TK, Fung SC, Lam SH. Reconstruction with submental flap for aggressive orofacial cancer. Plast Reconstr Surg 2007;120(02):431-436

49 Jiang B, Gu Y, Chen W. [Submental island flaps for reconstruction of hypopharyngeal non-circumferential defects after hypopharyngeal carcinoma removal]. Zhongguo Xiu Fu Chong Jian Wai Ke Za Zhi 2006;20(12):1183-1185

50 Yamauchi M, Yotsuyanagi T, Ezoe K, Saito T, Ikeda K, Arai K. Reverse facial artery flap from the submental region. J Plast Reconstr Aesthet Surg 2010;63(04):583-588

51 Abouchadi A, Capon-Degardin N, Patenôtre P, Martinot-Duquennoy $\mathrm{V}$, Pellerin $P$. The submental flap in facial reconstruction: advantages and limitations. J Oral Maxillofac Surg 2007;65(05): 863-869 